\title{
KUALITAS DAGING IKAN KURISI (Nemipterus japonicus) HASIL TANGKAPAN NELAYAN DI PELABUHAN PERIKANAN BRANTA, PAMEKASAN
}

\author{
Abdus Salam Junaedi*, Fortunata Riana, Harfatia Chandra Puspita Sari, Witria, \\ Muhammad Zainuri
}
Program Studi Manajemen Sumberdaya Perairan, Jurusan Ilmu Kelautan dan Perikanan, Universitas
Trunojoyo Madura, PO BOX 2 Kamal-Bangkalan
^Korespondensi: abdus.salamj@trunojoyo.ac.id
Diterima: 15 November 2019/ Disetujui: 07 Juli 2020

Cara sitasi: Junaedi AS, Riana F, Sari HCPS, Witria, Zainuri M. 2020. Kualitas daging ikan kurisi (Nemipterus japonicus) hasil tangkapan nelayan di Pelabuhan Perikanan Branta, Pamekasan. Jurnal Pengolahan Hasil Perikanan Indonesia. 23(2): 303-319.

\begin{abstract}
Abstrak
Kontrol mutu hasil tangkapan nelayan di Pelabuhan Perikanan Branta, Pamekasan masih belum dilaksanakan dengan baik. Penelitian ini bertujuan untuk menentukan kualitas daging ikan kurisi berdasarkan nilai Total Plate Count (TPC), keanekaragaman jenis, total kelimpahan jenis bakteri heterotrof dan patogen pada media TSA, EMB, SSA, dan TCBS. Nilai TPC bakteri heterotrof (TSA) adalah 8,59 Log CFU/g dengan 7 keanekaragaman jenis dan total kelimpahan tertinggi antara 2-336 koloni (BH3). Nilai TPC bakteri patogen (EMB) adalah 3,72 Log CFU/g dengan 6 keanekaragaman jenis dan total kelimpahan tertinggi antara 784-1009 koloni (BPE4), serta isolat bakteri BPE1 yang berwarna hijau metalik diduga sebagai Escherichia coli. Nilai TPC bakteri patogen (SSA) adalah 4,12 Log CFU/g dengan 5 keanekaragaman jenis dan total kelimpahan tertinggi antara 35-450 koloni (BPS1), serta isolat bakteri BPS1 yang berwarna hitam diduga sebagai Salmonella sp. Nilai TPC bakteri patogen (TCBS) adalah 5,41 Log CFU/g dengan 2 keanekaragaman jenis dan total kelimpahan tertinggi antara 0-44 koloni (BPT1). Isolat bakteri BPT1 dan BPT2 yang berwarna hijau dan kuning diduga sebagai Vibrio parahaemolyticus dan Vibrio vulnificus.
\end{abstract}

Kata kunci: Escherichia coli, Nemipterus japonicus, Salmonella sp, Vibrio parahaemolyticus, Vibrio vulnificus

\section{Quality of Kurisi Meat (Nemipterus japonicus), Results of Fisherman Catching in Branta Fishing Port, Pamekasan}

\begin{abstract}
Quality control over the catch of fishermen in the Branta Fishery Port, Pamekasan is still not well-implemented. This study was aimed to evaluate the quality of kurisi fish meat based on the value of the Total Plate Count (TPC), diversity and total heterotrophic bacteria and pathogens on TSA, EMB, SSA, and TCBS media. The heterotrophic bacterial TPC (TSA) value was $8.59 \mathrm{Log}$ CFU/g with 7 species diversity and the highest total of species abundance was between 2-336 colonies (BH3). The pathogenic bacterial TPC (EMB) value was $3.72 \mathrm{Log}$ CFU/g with 6 species diversity and the highest total of species abundance was between 784-1009 colonies (BPE4). The BPE1 bacterial isolate which was metallic green was suspected to be Escherichia coli. The pathogenic bacterial TPC (SSA) value was $4.12 \mathrm{Log}$ CFU/g with 5 species diversity and the highest total of species abundance was between 35-450 colonies (BPS1), and the BPS1 bacterial isolate which was black was suspected to be Salmonella sp. The pathogenic bacterial TPC (TCBS) value was 5.41 Log CFU/g with 2 species diversity and the highest total of species abundance was between 0-44 colonies (BPT1). The green and yellow BPT1 and BPT2 bacterial isolate were suspected to be Vibrio parahaemolyticus and Vibrio vulnificus.
\end{abstract}

Keywords: Escherichia coli, Nemipterus japonicus, Salmonella sp., Vibrio parahaemolyticus, Vibrio vulnificus 


\section{PENDAHULUAN}

Ikan merupakan komoditas perairan yang rentan mengalami penurunan kualitas sehingga perlu penanganan yang baik, cepat, dan hati-hati agar daging ikan layak dikonsumsi (Markenih 2016). Sebagian besar tubuh ikan, khususnya kurisi memiliki kadar air rata-rata $70,84 \%$ dengan jutaan mikroba yang dapat hidup di dalam tubuh ikan (Ervianti et al. 2017). Ikan yang telah mati dengan kadar air tinggi memicu percepatan pembusukan pada ikan yang tidak ditangani dengan baik. Penanganan ikan harus dilakukan sejak ikan diangkat dari perairan sampai di tangan konsumen. Kualitas ikan di masyarakat belum dapat disimpulkan baik ataupun buruk sehingga harga ikan pun masih fluktuatif.

Berdasarkan data BPS Tahun 2017 yang diolah oleh Direktorat Jendral Penguatan Daya Saing Produk Kelautan dan Perikanan, nilai ekspor produksi perikanan Indonesia dengan kekayaan sumberdaya laut yang berpotensi dan melimpah pada tahun 2017 masih pada kisaran angka 4,09 miliar USD (KKP 2018). Hal ini dapat diketahui bahwa masih banyak sekali produk perikanan Indonesia yang belum terkualifikasi dan masuk pasar ekspor. Menurut Rahayu dan Adhi (2016) peningkatan jumlah ekspor masih di bawah batas optimum sumberdaya perikanan Indonesia, selain itu nilai ekonomi dan nlai guna produk terus menurun seiring dengan buruknya penanganan hasil perikanan.

Ikan-ikan yang banyak diminati oleh masyarakat, salah satunya adalah ikan kurisi (Nemipterus japonicus). Ikan kurisi merupakan salah satu ikan yang memiliki nilai ekonomis dengan pemanfaatan baik segar maupun olahan. Jumlah dan nilai produksi ikan kurisi mencapai 8.060,1 ton (Dinas Kelautan dan Perikanan Provinsi Jawa Timur 2018). Nilai ini merupakan nilai yang cukup besar sebagai indikasi tingginya minat masyarakat dalam mengonsumsi ikan kurisi. Tempat Pelelangan Ikan menjadi tempat yang sangat berpengaruh terhadap kelayakan ikan, karena ikan akan ditangani setelah mati dari kapal sampai di tangan pembeli. Kualitas ikan kurisi yang dipasarkan ditentukan juga oleh kualitas penanganan ikan kurisi di TPI (Rahmatang et al. 2019).

Kualitas ikan dapat dipengaruhi oleh kualitas air tempat hidup ikan tersebut. Air yang produktif tanpa adanya bakteri patogen akan menumbuhkan ikan-ikan segar dan sehat. Beberapa bakteri heterotrof yang biasa hidup di perairan antara lain Pseudomonas, Micrococcus, Sarcina, Staphylococcus, dan Flavobacterium. Escherichia coli dan Staphylococcus aureus merupakan bakteri patogen yang biasanya ditemukan pada produk perikanan terkait kurangnya sanitasi (Hamidah et al. 2019).

Menurut Murniyati dan Sunarman (2000) sebagian besar bakteri bersarang pada permukaan dan insang ikan, namun ia akan menyerang bagian daging saat ikan mengalami post rigor. Kondisi ini terjadi saat daging ikan mulai mengendur dan air masuk ke dalam serat-serat daging. Dalam hal ini, bakteri akan mudah berkembang pada air sehingga ikan yang telah mati akan cepat mengalami pembusukan. Violentina et al. (2015) mengisolasi bakteri pada pada ikan tongkol (Euthynnus affinis) antara lain Photobacterium leiognathi, Rothia nasinurium, Psychrobacter celer, Bacillus megaterium, Myroides phaeus, Psychrobacter faecalis, Acinetobacter johnsonii, Vagococcus fessus, Vibrio gallicus, Shewanella baltica, Shewanella algae, Yersinia ruckeri, Uruburuella testudinis, dan Aeromonas mulluscorum.

Laluraa et al. (2014) melaporkan jumlah rata-rata bakteri E. coli dan bakteri koliform total pada ikan selar (Selaroides sp.) yang telah diisolasi menggunakan media EMB. Ditemukan rata-rata bakteri E. coli sebanyak $1,3 \times 10^{2}-9,7 \times 10^{3} \mathrm{MPN} / 100 \mathrm{~g}$ dan jumlah ratarata bakteri koliform total sebanyak $1,2 \times 10^{3}$ CFU/g. Yuliani et al. (2016) juga melaporkan bahwa pada ikan kembung (Scomber sp.), terdapat sebanyak $36 \times 10^{5}$ sel bakteri koliform yang telah berhasil diisolasi menggunakan media MCA dan SSA. Hal ini menunjukkan banyak sekali bakteri yang ditemukan pada ikan baik segar maupun tak segar. Faktanya, belum banyak ikan-ikan hasil tangkapan para nelayan di pasaran yang telah dihitung jumlah maupun telah diidentifikasi jenis bakteri yang 
mengontaminasinya. Khususnya ikan kurisi, yang menjadi salah satu komoditas terbesar hasil tangkapan nelayan.

Selama ini belum diketahui bakteri apa saja yang dapat tumbuh dan mengontaminasi daging ikan kurisi, bahkan masih belum terdapat data atau informasi yang cukup jelas, terkait pengaruh infeksi bakteri tersebut terhadap kualitas daging ikan kurisi sebelum dipasarkan kepada masyarakat atau konsumen. Tujuan penelitian ini adalah untuk menentukan kualitas daging ikan kurisi di Tempat Pelabuhan Ikan Branta, Kabupaten Pamekasan dengan menghitung nilai Total Plate Count (TPC), keanekaragaman jenis, total kelimpahan baik bakteri heterotrof maupun patogen yang diisolasi menggunakan media TSA, EMB, SSA, dan TCBS.

\section{BAHAN DAN METODE Bahan dan Alat}

Sampel yang digunakan adalah ikan kurisi (N. japonicus) segar hasil tangkapan nelayan yang didaratkan di Pelabuhan Ikan Branta, Kabupaten Pemekasan, Jawa Timur pada titik koordinat $7^{\circ} 13^{\prime} 19.4^{\prime \prime S} 113^{\circ} 27^{\prime} 03.0$ "E. Sampel ikan kurisi yang digunakan berjumlah 25 ekor dengan berat rata-rata sebesar $32,52 \pm 7,48$ $\mathrm{g}$ dan panjang rata-rata sebesar $13,48 \pm 1,04$. Bahan yang digunakan pada penelitian ini antara lain es batu, $\mathrm{HgCl}_{2}$ (Merck), media TSA/Tryptone Soya Agar (Oxoid), EMB/ Eosin Methyline Blue (Oxoid), SSA/Salmonella Shigella Agar (Oxoid), dan TCBS/Thiosulfate Citrate Bile Salt Sucrose (Oxoid), larutan air fisiologis $(0,85 \% \mathrm{NaCl})$, larutan alkohol $70 \%$, dan spirtus.

Alat-alat yang digunakan dalam penelitian ini antara lain dissecting set, autoklaf (OSK 6500 AUTOCLAVE OGAWA SEIKI CO., LTD), kompor listrik (Rommeisbacher), magnetic stirrer, water bath (Julabo TW8), Incubator (Heraeus), vortex, Laminar Air Flow $(L A F)\left(\mathrm{ESCO}^{\circledR}\right)$, colony counter (GALAXY 230).

\section{Metode Penelitian Preparasi sampel ikan kurisi}

Penelitian ini diawali dengan melakukan kegiatan pengukuran panjang, berat total, dan berat daging ikan kurisi. Jumlah sampel ikan kurisi yang berhasil dibeli di Tempat Pelabuhan Ikan Branta, Kabupaten Pamekasan berjumlah 25 ekor.

\section{Isolasi bakteri heterotrof pada media TSA (Tryptone Soya Agar)}

Daging ikan kurisi dipisahkan dari tulang dan kulitnya sebanyak $10 \mathrm{~g}$, kemudian diencerkan ke dalam $90 \mathrm{~mL}$ larutan $\mathrm{NaCl}$ fisiologis. Satu $\mathrm{mL}$ larutan sampel induk diencerkan ke dalam $9 \mathrm{~mL}$ larutan $\mathrm{NaCl}$ fisiologis (larutan sampel seri pengenceran $\left.10^{-1}\right)$. Pengenceran dilakukan secara bertahap sampai pada larutan sampel seri pengenceran $10^{-7}$. Isolasi bakteri heterotrof menggunakan teknik pour plate, yaitu mengambil sebanyak $1 \mathrm{~mL}$ larutan sampel seri pengenceran $10^{-6}$ dan $10^{-7}$ (Ihsan et al. 2018), kemudian diinokulasikan ke dalam cawan petri. Sebanyak $15 \mathrm{~mL}$ media TSA, dituangkan ke dalam cawan petri. Homogenisasi dilakukan dengan cara menggerakkan cawan petri secara perlahan-lahan sehingga membentuk angka delapan. Setelah media TSA memadat, kemudian sampel diinkubasi pada suhu $28^{\circ} \mathrm{C}$ selama $1 \times 24$ jam (Lestari et al. 2016). Karakteristik bakteri heterotrof yang berhasil diisolasi pada media TSA adalah bermacammacam seperti putih, transparan, krem, kuning, bahkan kecokelatan.

\section{Isolasi bakteri patogen pada media eosin methylene blue (EMB)}

Kegiatan isolasi bakteri patogen dari sampel daging ikan kurisi pada media EMB dilakukan dengan metode dan teknik yang sama seperti kegiatan isolasi bakteri heterotrof sebelumnya. Akan tetapi, larutan sampel yang diisolasi berasal dari seri pengenceran $10^{-1}$ dan $10^{-2}$. Media yang digunakan adalah media spesifik untuk pertumbuhan bakteri kelompok Enterobacteriaceae, yaitu EMB. Setelah media EMB memadat, kemudian sampel diinkubasi pada suhu $37^{\circ} \mathrm{C}$ selama $2 \times 24$ jam (Rahmiati 2016). Karakteristik yang khas dari bakteri patogen E. coli yang berhasil diisolasi pada media EMB adalah koloni bakteri yang berwarna hijau metalik. 


\section{Isolasi bakteri patogen pada media salmonella shigella agar (SSA)}

Beberapa hal yang sama, seperti metode, teknik, asal larutan sampel, suhu dan lama waktu inkubasi yang dilakukan pada saat kegiatan isolasi bakteri patogen pada media EMB sebelumnya, juga dilakukan pada tahapan ini. Akan tetapi, media isolasi yang digunakan berbeda, yaitu media SSA yang merupakan media spesifik untuk pertumbuhan bakteri genus Salmonella dan Shigella. Koloni bakteri yang berwarna hitam merupakan karakteristik yang khas dari bakteri patogen Salmonella yang berhasil diisolasi pada media SSA (Rahmiati 2016).

\section{Isolasi bakteri patogen pada media thiosulfate citrate bile salt sucrose (TCBS)}

Isolasi bakteri patogen dari sampel daging ikan kurisipada media TCBS dilakukan dengan metode, teknik, dan suhu inkubasi yang sama seperti kegiatan isolasi bakteri patogen pada media EMB dan SSA sebelumnya. Media isolasi yang digunakan berbeda, yaitu media TCBS yang merupakan media spesifik untuk pertumbuhan bakteri genus Vibrio. Berbeda dengan kedua jenis media spesifik sebelumnya, setelah media TCBS memadat, sampel diinkubasi selama 1x24 jam (Devi et al. 2019). Karakteristik yang khas dari genus Vibrio pada media TCBS adalah warna koloni bakteri yang ditampakkan. Koloni bakteri yang berwarna hijau dan kuning merupakan bakteri Vibrio parahaemolyticus dan Vibrio vulnificus (Hikmawati et al. 2019).

\section{Karakterisasi keanekaragaman jenis koloni bakteri heterotrof dan patogen}

Karakterisasi keanekaragaman jenis koloni bakteri heterotrof dan patogen yang berhasil diisolasi dari media TSA, EMB, SSA, dan TCBS pada tahapan sebelumnya, diamati menggunakan karakter bentuk koloni, warna, tepian, dan elevasi (Sabdaningsih et al. 2013). Selain itu, juga terdapat karakter permukaan dan ukuran koloni yang diamati secara visual menggunakan kasat mata.

\section{Penghitungan total kelimpahan jenis koloni bakteri heterotrof dan patogen}

Penghitungan dilakukan dengan cara menghitung secara keseluruhan semua total koloni bakteri heterotrof dan patogen dari sampel ikan kurisi yang termasuk dalam jenis bakteri yang sama, kemudian dikalikan dengan faktor pengenceran tertentu yang telah ditumbuhkan baik dalam media umum maupun spesifik berdasarkan data keanekaragaman jenis pada tahapan karakterisasi keanekaragaman jenis koloni bakteri heterotrof dan patogen yang telah dilakukan pada tahapan sebelumnya (Wibowo dan Andrivani 2016).

\section{Analisis Data}

Analisis data hasil isolasi, karakterisasi, dan penghitungan total kelimpahan keanekaragaman jenis koloni bakteri heterotrof dan patogen dari sampel daging ikan kurisi dianalisis secara deskriptif berdasarkan visualisasi yang dihasilkan.

\section{HASIL DAN PEMBAHASAN Proporsi Ikan Kurisi}

Berdasarkan hasil kegiatan pengukuran panjang menggunakan alat ukur penggaris, dapat diketahui bahwa panjang rata-rata sampel ikan kurisi adalah 13,48+1,04 cm. Ukuran panjang standar maksimum ikan kurisi menurut Russell (1990) adalah $25 \mathrm{~cm}$ dan pada umumnya berukuran sekitar 15 $\mathrm{cm}$. Prabakaran et al. (2014) menyatakan panjang minimum dan maksimum ikan kurisi yang berhasil ditangkap dari Pantai Chennai, India adalah $11,4 \mathrm{~cm}$ dan $26,7 \mathrm{~cm}$ dengan panjang rata-rata sebesar $16,61+2,77$ $\mathrm{cm}$. Hasil pengukuran panjang ikan kurisi yang ditangkap di daerah Pantai Utara dan Selatan India oleh Rao et al. (2017) adalah $33,02 \mathrm{~cm}$ dan $29,87 \mathrm{~cm}$. Hasil tangkapan ikan kurisi sejak periode Agustus 2017 sampai Maret 2018 di Pantai Saurastra, Gujarat yang berhasil diukur panjang totalnya oleh Sarman et al. (2018) berkisar antara 7,9-44,5 $\mathrm{cm}$. 
Perbedaan ukuran panjang ikan kurisi dipengaruhi oleh faktor intrinsik dan ekstrinsik. Faktor intrinsik yang paling dominan menentukan perbedaan ukuran ikan kurisi adalah jenis kelamin. Menurut ElHaweet (2013), ikan kurisi betina lebih banyak memanfaatkan energinya untuk pertumbuhan gonad dibandingkan pertumbuhan tubuh atau somatiknya. Akibatnya, ikan kurisi betina lebih banyak ditemukan dalam ukuran yang lebih kecil dibandingkan dengan ikan kurisi jantan. Ketika proses pematangan gonad lebih cepat dibandingkan dengan ikan kurisi jantan, maka ikan kurisi betina akan lebih cepat mati sehingga ikan kurisi jantan akan lebih banyak ditemukan pada ukuran-ukuran besar. Selain faktor intrinsik, perbedaan ukuran panjang juga dapat dipengaruhi oleh faktor ekstrinsik. Amine (2012) menjelaskan bahwa perbedaan jumlah ketersedian makanan, suhu perairan, dan kepadatan stok dapat memengaruhi panjang ikan dan ukuran pertama kali matang gonad.

Adapun penimbangan berat total ikan kurisi menggunakan timbangan digital, dapat diketahui bahwa rata-rata berat total sampel ikan kurisi adalah 32,52 $\pm 7,48$ g. Amine (2012) melaporkan berat total maksmial ikan kurisi yang ditangkap di Teluk Suez, Mesir adalah 219,2 g. Afshari et al. (2013) juga melaporkan hasil penimbangan berat total minimum dan maksimum ikan kurisi yang ditangkap dari Laut Oman Utara, yaitu sebesar 55,31 dan 288,12 g. Oktaviyani et al. (2016) juga menyatakan bahwa berat total ikan kurisi yang ditangkap dari Teluk Banten berkisar antara 20-125 g. Berat total ikan kurisi yang berhasil dikumpulkan oleh Aung (2019) dari bulan Januari sampai Desember 2018 di tempat pendaratan ikan Thabaw-seik, Myanmar berkisar antara 30-239 g. Adanya perbedaan berat ikan kurisi dapat dipengaruhi oleh faktor usia dan jenis makanan yang dimakan seperti fitoplankton, zooplankton, makroavertebrata bentik, ikan, dan detritus (Asriyana dan Syafei 2012). Berat daging ikan kurisi pada penelitian ini yaitu $12,59 \pm 3,61 \mathrm{~g}$.

\section{Total Bakteri Heterotrof dan Patogen}

TPC merupakan salah satu metode yang dapat digunakan untuk menghitung jumlah mikroba dalam bahan pangan. Metode ini merupakan metode yang paling banyak digunakan dalam analisis karena koloni dapat dilihat secara langsung dengan mata tanpa menggunakan alat mikroskop (Nurhayati dan Samallo 2013). Berdasarkan Figure 1, dapat diketahui bahwa kegiatan isolasi bakteri heterotrof dan patogen dari sampel daging ikan kurisi pada masing-masing jenis media menunjukkan nilai TPC (Total Plate Count) yang berbeda.

Total bakteri heterotrof pada media Tryptone Soya Agar (TSA) adalah 8,59 log $\mathrm{CFU/g}$ (Figure 1). International Commision on Microbiological Specification For Food (ICMSF 1986) dan Badan Standardisasi Nasional (BSN 2006) menetapkan bahwa standar maksimal untuk kontaminan total bakteri yang terdapat pada ikan yang didinginkan adalah $5 \times 10^{5}$ atau setara dengan 5,69 log CFU/g. CSN 569609 (2008) juga menentukan bahwa standar maksimal untuk kontaminan total bakteri yang terdapat pada ikan adalah $5 \times 10^{6}$ atau setara dengan $6,7 \log \mathrm{CFU} / \mathrm{g}$. Hal yang serupa juga dinyatakan oleh Ingr (2010) terkait standar maksimal untuk kontaminasi total bakteri pada ikan, yaitu $1 \times 10^{6}$ atau setara dengan 6 $\log \mathrm{CFU} / \mathrm{g}$. Berdasarkan standar nilai tersebut, maka hasil nilai TPC bakteri heterotrof pada penelitian ini melebihi dari standar nilai yang ditetapkan oleh ICMSF, BSN, CSN 569609, dan Ingr (2010).

Hasil penelitian ini berbeda dengan nilai total viable count (TVC) pada sampel ikan kurisi yang diisolasi oleh Sankar et al. (2013) dari daerah Pesisir Mudasaloda, Tamil Nadu, Pantai Tenggara India dengan nilai sebesar $3,4 \times 10^{5}$ atau setara dengan nilai 5,53 log CFU/g. Babu dan Rao (2014) juga melaporkan hasil yang berbeda dengan penelitian ini, nilai total bacterial count (TBC) dari sampel ikan kurisi yang diisolasi dari Pelabuhan Penangkapan Ikan Visakhapatnam, Pantai Timur India adalah $2,60 \times 10^{4}$ atau setara dengan 4,41 log $\mathrm{CFU} / \mathrm{g}$. Kedua penelitian ini masih berada dalam kategori yang distandarkan oleh ICMSF, BSN, CSN 569609, dan Ingr (2010).

Bakteri heterotrof adalah kelompok bakteri yang mampu memanfaatkan bahan organik maupun anorganik pada lingkungan tempat tumbuhnya sebagai sumber nutrisi 
(Luo et al. 2010). Bakteri heterotrof mempunyai kemampuan untuk menggunakan C-organik sebagai sumber karbon dan sumber energi untuk pertumbuhannya (Chatterjee et al. 2014). Didalam ekosistem laut, bakteri heterotrof berperan aktif sebagai pengurai materi-materi organik menjadi unsur-unur mineral yang esensial (Agustiyani et al. 2010).

Total bakteri heterotrof yang diisolasi menggunakan jenis media TSA menunjukkan nilai yang tertinggi $(8,59 \log \quad \mathrm{CFU} / \mathrm{g})$ dibandingkan dengan nilai total bakteri patogen yang diisolasi menggunakan jenis media yang lainnya, secara berurutan sebesar 5,41 log CFU/g, 4,12 log CFU/g, dan 3,72 log CFU/g pada media TCBS, SSA, dan EMB (Figure 1). Rosmaniar (2011) menyatakan bahwa bakteri heterotrof dibedakan menjadi bakteri saprofit dan bakteri patogen. Bakteri saprofit berupaya memenuhi kebutuhan nutrisinya dari sisa-sisa makhluk hidup yang telah mati atau dari lingkungan, sedangkan bakteri patogen berusaha memperoleh makananannya dengan cara mengambil senyawa organik dari makhluk hidup lain. Hal ini dapat terjadi karena bakteri patogen merupakan bakteri yang lebih spesifik dan mempunyai karakteristik yang khas untuk dapat menginvasi dan menginfeksi suatu jaringan yang berakibat terdapatnya penyakit pada sampel daging ikan kurisi. Adanya sifat yang khas yang ditunjukkan oleh masingmasing jenis bakteri yang diduga kuat sebagai bakteri patogen ini menjadikan nilai total pada masing-masing cawan petri yang berisi beberapa jenis media spesifik juga berbeda dan cenderung menunjukkan populasi yang lebih sedikit dibandingkan dengan populasi bakteri heterotrofnya.

Total bakteri patogen koliform pada media EMB adalah 3,72 log CFU/g (Figure 1). Menurut International Association of Microbiological Societies (IAMS, 1962), standar total bakteri koliform dan koliform fekal yang terdapat pada ikan maksimum adalah $100 \mathrm{MPN} / \mathrm{g}$ dan $11 \mathrm{MPN} / \mathrm{g}$ atau setara dengan $1 \times 10^{4} \mathrm{CFU} / \mathrm{g}(4 \mathrm{Log} \mathrm{CFU} / \mathrm{g})$ dan $1,1 \times 10^{3} \mathrm{CFU} / \mathrm{g}(3,04 \mathrm{Log} \mathrm{CFU} / \mathrm{g})$. Standar nilai ini diperketat kembali oleh International Commision on Microbiological Specification
For Food (ICMSF, 1986) yang menetapkan bahwa standar nilai TPC bakteri koliform dan koliform fekal pada ikan segar dan ikan yang didinginkan adalah $<100 \mathrm{MPN} / \mathrm{g}$ dan $<10 \mathrm{MPN} / \mathrm{g}$ atau setara dengan $1 \times 10^{4}(4 \mathrm{Log}$ $\mathrm{CFU} / \mathrm{g}$ ) dan $1 \times 10^{3} \mathrm{CFU} / \mathrm{g}$ (3 Log CFU/g).

Hal yang sama juga ditetapkan oleh Badan Standardisasi Nasional (2006) terkait standar nilai TPC bakteri koliform, adapun standar nilai koliform fekal pada ikan segar lebih diperketat, yaitu $<3 \mathrm{MPN} / \mathrm{g}$ atau setara dengan $3 \times 10^{2}$ (2,47 Log CFU/g). Berdasarkan standar nilai tersebut, maka nilai TPC bakteri patogen koliform pada penelitian ini tidak melebihi dari standar nilai yang ditetapkan oleh IAMS, ICMSF, dan BSN. Akan tetapi, hasil penelitian ini berbeda dengan penelitian Geetha et al (2014) yang menyatakan bahwa nilai perhitungan total bakteri koliform yang berhasil diisolasi dari spesies Nemipterus japonicus adalah $160 \mathrm{MPN} / \mathrm{g}$ yang setaradengan $1,6 \times 10^{4}$ atau $4,2 \log \mathrm{CFU} / \mathrm{g}$.

Total bakteri koliform yang rendah pada penelitian ini dibandingkan dengan standar nilai yang ditentukan menunjukkan adanya efektivitas prosedur keselamatan selama pemrosesan dan penanganan (Elhadi et al. 2004). Bakteri koliform termasuk dalam kelompok dari Famili Enterobacteriaceae yang berperan penting dalam proses pembusukan makanan karena kemampuannya dalam memetabolisme komponen asam amino menjadi beberapa senyawa yang bersifat volatil (Remenanta et al. 2015). Besarnya kuantitas koliform yang tinggi dikaitkan terutama pada perlakuan yang salah dan tidak disimpan mengggunakan suhu penyimpanan (Gorner dan Valik 2004). Kehadiran koliform total merupakan indikator terjadinya kontaminasi limbah yang mungkin juga terjadi selama tahapan pemrosesan yang berbeda-beda seperti pengangkutan dan penanganan (Sanje dan Karim 2016). Indikator yang lebih akurat dari adanya kontaminasi fekal adalah hadirnya bakteri E. coli (Suvanich et al. 2000) yang ditandai dengan terbentuknya koloni bakteri yang berwarna hijau metalik.

Nilai total bakteri patogen pada media SSA adalah 4,12 log CFU/g (Figure 1). Menurut International Association of Microbiological Societies (IAMS 1962), ikan 
segar atau ikan yang didinginkan akan mempunyai kualitas yang baik apabila sama sekali tidak terkontaminasi oleh kelompok Salmonella spp. (0/g). Commission Regulation (ES) 2073 (2005) juga mengeluarkan standar nilai kontaminasi untuk bakteri Salmonella pada ikan segar, yaitu setiap $25 \mathrm{~g}$ sampel ikan segar tidak boleh ditemukan kontaminasi bakteri Salmonella sp. Standar nilai yang sama juga dinyatakan oleh Badan Standardisasi Nasional, yaitu negatif/25 g sampel ikan segar (BSN 2009).

Patil et al. (2013a) melaporkan bahwa tidak menemukan adanya kontaminasi bakteri Salmonella pada produk perikanan "Fish Mince Pakoda (FMP)" yang berasal dari daging ikan N. japonicus. Patil et al. (2013b) juga menegaskan kembali terkait tidak adanya kontaminasi bakteri Salmonella pada sampel daging ikan N. japonicus yang diisolasi dari Pasar Ikan Shirgaon, Ratnagiri, India dengan suhu pendinginan $4^{\circ} \mathrm{C}$. Berdasarkan ketiga standar nilai tersebut, maka total bakteri patogen pada media Salmonella Shigella Agar (SSA) melebihi standar nilai yang ditentukan oleh IAMS, Commission Regulation (ES) 2073, BSN dan bertolak belakang dengan hasil penelitian Patil et al. (2012; 2013). Akan tetapi, hasil penelitian ini didukung oleh Babu dan Rao (2014) yang menemukan adanya bakteri Salmonella sp. pada kebanyakan sampel ikan yang dikoleksi, salah satunya pada ikan $N$. japonicus.

Kehadiran Salmonella dalam makanan laut dapat berasal dari kontaminasi yang terjadi di perairan lingkungan alami, aktivitas budidaya, atau kontaminasi silang selama proses penyimpanan, transportasi, dan pemrosesan (Amagliani et al. 2012). Salmonella spp. adalah bakteri yang sangat patogen, Babu dan Rao (2014) menambahkan bahwa kehadiran bakteri Salmonella aureus mengindikasikan adanya kontaminasi ikan dan lingkungan alam oleh manusia dan hewan berdarah panas. Kehadiran Salmonella pada ikan ini telah terdeteksi di beberapa Negara Asia dan Afrika (Terenjeva et al. 2015). Pencemaran oleh manusia atau kotoran hewan dapat menjadi alasan utama tingginya angka prevalensi Salmonella pada sampel ikan air tawar (Yang et al. 2015) dan pada akhirnya semuanya akan bermuara pada perairan laut.

Total bakteri patogen pada media TCBS adalah 5,41 log CFU/g (Figure 1). International Association of Microbiological Societies (IAMS, 1962) mensyaratkan standar nilai bakteri Vibrio sp. pada ikan segar dan ikan yang didinginkan sebesar 0/g. CSN 569609 (2008) menyatakan bahwa standar maksimal untuk kontaminasi bakteri Vibrio parahaemolyticus yang terdapat pada ikan adalah 0/25 g.

Badan Standardisasi Nasional (2009) juga menetapkan standar nilai yang sama dengan CSN 569609 (2008) terkait hal ini, yaitu negatif/25 g. Berdasarkan standar nilai tersebut, maka nilai TPCbakteri patogen Vibrio pada penelitian ini dari standar nilai yang dinyatakan oleh IAMS, CSN 569609, dan BSN. Penelitian ini didukung oleh Babu dan Rao (2014) yang melaporkan adanya kontaminasi terbesar bakteri Vibrio sp. pada ikan $N$. japonicus dibandingkan kontaminasinya pada ikan Upenues vittatus dan Prianthus hamrur.

Kontaminasi Vibrio sp. adalah penyebab yang paling sering dilaporkan dari wabah terkait makanan laut yang bersifat toksigenik (Iwamoto et al. 2010). Kehadiran Vibrio spp. pada ikan dapat menyebakan terjadinya infeksi pada konsumen (Babu dan Rao 2014). V.parahaemolyticus tersebar luas dilingkungan laut dan dianggap sebagai penyebab utama terjadinya gastroenteritis pada manusia (Alaboudi et al. 2016). Hal yang sama juga diperankan oleh bakteri $V$. vulnificus. Infeksi bakteri ini dapat terjadi akibat mengonsumsi atau menangani makanan laut yang terkontaminasi (biasanya kerang seperti tiram) atau dari adanya luka yang terbuka atau kulit yang pecah akibat adanya air laut atau air payau yang terkontaminasi (Horseman dan Surani 2011). Kedua bakteri patogen ini erat kaitannya dengan produk perikanan dan hasil laut (Komprda 2004). Jumlah yang lebih tinggi dari sepesies Vibrio pada ikan telah dibuktikan oleh Aagesen dan Hase (2014), terutama ketika terjadi pelanggaran rantai pendingin atau fluktuasi suhu berulang, atau terjadinya wabah besar berupa kondisi bulan yang lebih hangat (Fernandes 2009).

Komposisi otot ikan menjadi lingkungan yang sangat disukai oleh mikroba untuk 


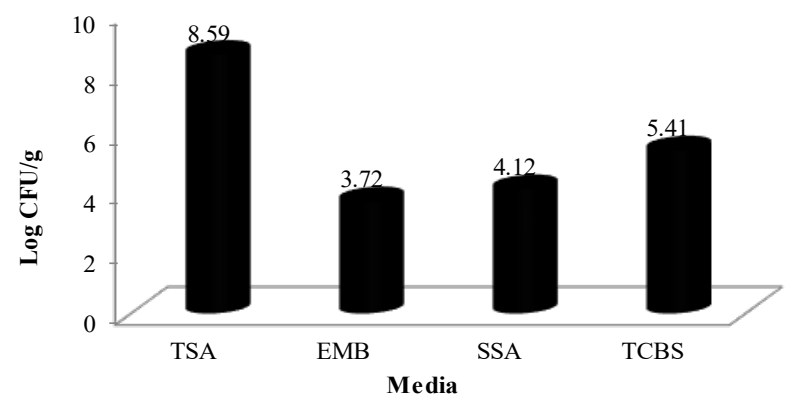

Figure 1 Values of heterotrophic bacteria and pathogenic bacteria ( $\log$ CFU / g) on TSA, EMB, SSA, and TCBS media.

melakukan aktivitas pertumbuhan. Dengan demikian kontaminasi ikan dapat terjadi selama proses penyimpanan (Souza et al. 2010), terutama saat dipindahkan dari tempat penangkapan ikan ke tempat pendaratan ikan. Sanje dan Karim (2015) melaporkan bahwa air dan es adalah faktor yang paling penting dalam proses penanganan ikan. Kedua faktor ini berkontribusi dalam menentukan dan mempertahankan kualitas standar ikan yang didinginkan.

Lokollo dan Mailoa (2020) menambahkan bahwa penanganan yang terlambat membuat pertumbuhan bakteri semakin pesat sehingga ikan menjadi busuk yang ditandai dengan permukaan tubuh berlendir, daging menjadi lembek, dan berbau busuk dari senyawa antara lain: indol, skatol, merkaptan, ammonia, asam sulfit, dan lain-lain. Di samping itu, ikan juga mempunyai komponen air yang cukup besar (Kurniawan et al. 2012) sehingga apabila dibiarkan pada suhu kamar, maka akan cepat mengalami proses pembusukan. Akibatnya, baik bakteri heterotrof maupun patogen yang berada di perairan melakukan proses invasi dilanjutkan dengan proses infeksi pada jaringan sampel daging ikan kurisi.

\section{Keanekaragaman Jenis Koloni Bakteri Heterotrof dan Patogen}

Kegiatan ini dilakukan dengan cara mendeterminasikan masing-masing jenis koloni bakteri heterotrof dan patogen yang tumbuh dengan beberapa karakter morfologi seperti warna, bentuk, tepian, elevasi, permukaan, dan ukuran seperti yang disajikan pada Table 1-4. Table 1 menunjukkan bahwa jenis koloni bakteri heterotrof yang berhasil diisolasi dari sampel daging ikan kurisi berjumlah tujuh jenis. Masing-masing jenis koloni bakteri heterotrof mempunyai karakter morfologi yang berbeda, terutama pada karakter warna koloni bakteri. Selebihnya pada karakter tepian, elevasi, dan permukaan koloni bakteri heterotrof menunjukkan karakteristik yang sama, yaitu rata (entire), cembung (convex), dan halus.

Karakter bentuk koloni, hanya jenis koloni bakteri heterotrof $\mathrm{BH} 6$ yang menunjukkan karakteristik yang berbeda dengan jenis koloni

Table 1 Heterotrophic bacterial colonies characteristics from samples of kurisi fish meat on TSA media

\begin{tabular}{llllllll}
\hline \multirow{2}{*}{$\begin{array}{c}\text { Macroscopic } \\
\text { Characteristic }\end{array}$} & \multicolumn{7}{c}{ Bacterial Colony Species } \\
\cline { 2 - 7 } & BH1 & \multicolumn{1}{c}{$\mathrm{BH} 2$} & $\mathrm{BH} 3$ & $\mathrm{BH} 4$ & $\mathrm{BH}$ & $\mathrm{BH}$ & $\mathrm{BH}$ \\
\hline Color & white & faded white & white & transparent & faded cream & yellow & tawny \\
Form & circular & circular & circular & circular & circular & irreguler & circular \\
Margin & entire & entire & entire & entire & entire & entire & entire \\
Elevation & convex & convex & convex & convex & convex & convex & convex \\
Surface & smooth & smooth & smooth & smooth & smooth & smooth & smooth \\
Size & moderate & moderate & small & moderate & moderate & moderate & moderate \\
\hline Note: $\mathrm{BH}=$ Heterotrophic bacteria & & & & & &
\end{tabular}

Note: $\mathrm{BH}=$ Heterotrophic bacteria 
Table 2 Heterotrophic bacterial colonies characteristics from samples of kurisi fish meat on EMB media

\begin{tabular}{lllllll}
\hline \multirow{2}{*}{$\begin{array}{c}\text { Macroscopic } \\
\text { Characteristic }\end{array}$} & \multicolumn{7}{c}{ BPE1 } & BPE2 & BPE3 & BPE4 & BPE5 & BPE6 \\
\cline { 2 - 7 } Color & metallic green & $\begin{array}{l}\text { purplish } \\
\text { pink }\end{array}$ & yellow & purple & white & transparent \\
Form & circular & circular & circular & circular & circular & circular \\
Margin & entire & entire & entire & entire & entire & entire \\
Elevation & convex & convex & convex & convex & convex & flat \\
Surface & smooth & smooth & smooth & smooth & smooth & smooth \\
Size & moderate & small & moderate & small & moderate & moderate \\
\hline Note: BPE = Pathogenic bacteria on EMB & & & & &
\end{tabular}

bakteri heterotrof yang lainnya, yaitu tepian yang bergerigi. Jenis koloni bakteri heterotrof BH3 juga menunjukkan karakteristik yang berbeda dengan jenis koloni bakteri heterotrof yang lainnya pada karakter ukurannya, yaitu berukuran kecil (small). Cappucino dan Suherman (2002) menegaskan bahwa keragaman bentuk morfologi koloni bakteri dapat mengindikasikan bahwa masing-masing koloni memiliki karakter yang berbeda Sari (2014) menambahkan bahwa penampakan morfologi koloni yang berbeda-beda yang ditandai dengan adanya karakteristik yang berbeda-dapa dapat mengindikasikan bahwa koloni bakteri tersebut berasal dari spesies yang berbeda.

Ditemukan enam jenis koloni bakteri patogen dari sampel daging ikan kurisi pada media EMB (Table 2). Semua jenis koloni bakteri patogen ini memiliki karakteristik warna yang berbeda. Pada karakter bentuk, tepian, dan permukan, semua jenis koloni bakteri patogen ini memiliki karakteristik yang sama, yaitu tepian yang teratur (circular), rata (entire), dan halus. Pada karakter elevasi, hanya jenis koloni bakteri patogen BPE6 yang menunjukkan karakteristik yang berbeda, yaitu datar (flat). Bakteri akan bereproduksi atau membelah diri pada media agar dan membentuk koloni setelah 18-24 jam inkubasi. Pertumbuhan bakteri yang terus menerus akan menyebabkan kompetisi dalam mendapatkan nutrisi atau bahan makanan antara sel inang dengan sel hasil pembelahan/pertumbuhan (Rinawati et al. 2015). Dalam kondisi seperti ini, mekanisme adaptasi pertumbuhan yang dilakukan adalah dengan melakukan pertumbuhan ke atas. Elevasi merupakan derajat kenaikan pertumbuhan koloni di atas permukaan agar yang dikelompokkan menjadi flat (rata), raised (timbul), convex (cembung), dan unbonate (cembung di bagian tengah lebih menonjol) (Cappucino dan Suherman 2002).

Adapun pada karakter ukuran, jenis koloni bakteri patogen BPE2 dan BPE4 memiliki karakteristik yang sama, yaitu kecil (small). Rinawati et al. (2015) menjelaskan bahwa ukuran koloni bakteri dipengaruhi oleh keadaan lingkungan, medium, dan usia. Pada umumnya bakteri yang usianya lebih muda mempunyai ukuran yang relatif lebih besar daripada yang sudah tua. Ukuran bakteri ini juga dipengaruhi oleh jumlah koloni bakteri yang tumbuh pada suatu media. Semakin banyaksuatu bakteritumbuh pada suatu media, maka akan terjadi suatu persaingan dalam ruang/tempat hidup bakteri tersebut sehingga pembelahan atau pertumbuhan koloni dapat menjadi baik, ataupun sebaliknya, dapat juga terjadi persaingan dalam mendapatkan nutrisi pada media tersebut, dan persaingan antara spesies bakteri, mupun bakteri yang tumbuh dengan inangnya.

Media EMB digunakan untuk proses isolasi dan identifikasi bakteri enterik atau koliform. Bakteri yang diinokulasikan pada media EMB menghasilkan koloni dengan warna hijau metalik yang merupakan bakteri E. coli. Jika memiliki warna pink, maka merupakan bakteri Klebsiella $s p$ dan Enterobacter aerogenes. Media EMB 
Table 3 Heterotrophic bacterial colonies characteristics from samples of kurisi fish meat on TSA SSA media

\begin{tabular}{|c|c|c|c|c|c|}
\hline \multirow{2}{*}{$\begin{array}{l}\text { Macroscopic } \\
\text { Characteristic }\end{array}$} & \multicolumn{5}{|c|}{ Bacterial Colony Species } \\
\hline & BPS1 & BPS2 & BPS3 & BPS4 & BPS5 \\
\hline Color & black & deep white & deep pink & pink & fawn \\
\hline Form & circular & circular & circular & circular & circular \\
\hline Margin & entire & entire & entire & entire & entire \\
\hline Elevation & convex & convex & convex & convex & convex \\
\hline Surface & smooth & smooth & smooth & smooth & smooth \\
\hline Size & moderate & moderate & small & moderate & moderate \\
\hline
\end{tabular}

Table 4 Species diversity of heterotrophic bacterial colonies from samples of kurisi fish meat on TCBS media

\begin{tabular}{|c|c|c|}
\hline \multirow[t]{2}{*}{$\begin{array}{l}\text { Macroscopic } \\
\text { Characteristic }\end{array}$} & \multicolumn{2}{|c|}{$\begin{array}{c}\text { Bacterial Colony } \\
\text { Species }\end{array}$} \\
\hline & BPT1 & ВРT2 \\
\hline Color & green & yellow \\
\hline Form & circular & circular \\
\hline Margin & entire & entire \\
\hline Elevation & convex & convex \\
\hline Surface & smooth & smooth \\
\hline
\end{tabular}

mengandung sejumlah laktosa sehingga dapat membedakan golongan bakteri dengan proses fermentasi laktosa, salah satunya adalah bakteri E. coli. Bakteri ini mampu memfermentasi laktosa dengan cepat dan memproduksi banyak asam sehingga mampu menghasilkan warna koloni hijau metalik (Brooks et al. 2013). Koloni bakteri E. coli yang tumbuh memiliki tepian rata, elevasi cembung, permukaan halus, dan berwarna hijau metalik. Hal ini sesuai dengan penelitian yang dilakukan oleh Khakim dan Rini (2018) menggunakan 3 kali ulangan sampel yang ditumbuhkan pada media selektif EMB.

Terdapat lima jenis koloni bakteri patogen dari sampel daging ikan kurisi pada media SSA (Table 3). Semua jenis koloni bakteri patogen ini menunjukkan warna koloni bakteri yang berbeda-beda. Pada karakter bentuk, tepian, elevasi, dan permukaan koloni bakteri, semua jenis koloni bakteri patogen ini menunjukkan karakteristik yang sama, yaitu tepian yang teratur (circular), rata (entire), cembung (convex), dan halus. Dari kelima jenis koloni bakteri patogen ini, hanya terdapat satu jenis koloni bakteri patogen, yaitu BPS3 yang mempunyai ukuran kecil dibandingkan dengan jenis koloni bakteri patogen lainnya yang berukuran sedang. Hal ini dapat dipengaruhi oleh aktivitas pertumbuhan bakteri. Pertumbuhan bakteri yang terus menerus akan menyebabkan terjadinya kompetisi dalam mendapatkan nutrisi/bahan makanan antara sel inang dengan sel hasil pembelahan/pertumbuhan (Rinawati et al. 2015). Bakteri yang tidak mampu bersaing untuk mendapatkan nutrisi/bahan makanan akan mengalami aktivitas pertumbuhan yang lambat sehingga akan berukuran kecil.

Romadhon (2016) berhasil mengisolasi bakteri Salmonella dengan koloni putih dengan titik hitam. Hal ini juga didukung oleh Khakim dan Rini (2018) yang berhasil mengisolasi bakteri Salmonella dengan ciri makroskopis berbentuk bulat dengan permukaan rata, memiliki warna cerah transparan dengan ini hitam pada bagian tengah atau tidak, dan mampu memproduksi $\mathrm{H}_{2} \mathrm{~S}$ dengan terbentuknya warna hitam. Engelkirk dan Duben (2008) menyatakan 
karakteristik koloni bakteri Salmonella pada media selektif SSA sebagai media pertumbuhannya. Selama proses inkubasi 24 jam dengan suhu $37^{\circ} \mathrm{C}$, bakteri Salmonella memiliki koloni tak berwarna sampai merah muda dan memiliki warna bening sampai buram dan bintik hitam di bagian tengah. Pelczar dan Chan (2007) menambahkan bahwa adanya warna merah muda pada isolat dikarenakan adanya kelompok koliform lain yang tumbuh, karena koloni mikroba pada alam jarang sekali ditemukan dalam bentuk tunggal atau dalam satu jenis, melainkan dalam bentuk campuran

Berbeda dengan jenis koloni bakteri patogen lainnya, pada media TCBS hanya ditemukan dua jenis koloni bakteri patogen dari sampel daging ikan kurisi (Table 4). Masing-masing karakteristik yang dimiliki oleh kedua jenis koloni bakteri patogen ini adalah sama pada beberapa karakternya. Hanya saja pada karakter warna koloni bakteri, masing-masing dari jenis koloni bakteri patogen menunjukkan perbedaan warna. Ihsan dan Retnaningrum (2017) melaporkan koloni bakteri Vibrio yang tumbuh pada media TCBS memiliki beberapa sifat morfologi koloni; wana koloni (kuning, orange, hijau, dan hijau kebiruan), bentuk koloni circular, tepi koloni entire, dan elevasi koloni yang bermacam-macam (law conver, conver, dan effuse). Menurut Mailoa dan Setha (2011), warna koloni yang berwarna hijau pada bakteri Vibrio disebabkan karena sifatnya yang tidak mampu memfermentasi sukurosa, sedangkan warna koloni yang berwarna kuning mampu memfermentasi sukrosa serta mampu menurunkan $\mathrm{pH}$ pada media TCBS.

\section{Total Kelimpahan Jenis Koloni Bakteri Heterotrof dan Patogen}

Total kelimpahan jenis koloni bakteri heterotrof dan patogen dari sampel daging ikan kurisi disajikan pada Figure 2, 3, 4, 5. Berdasarkan Figure 2 dapat diketahui bahwa total kelimpahan jenis koloni bakteri heterotrof pada masing-masing jenis koloni bakteri heterotrof adalah berbeda-beda. Total kelimpahan jenis koloni bakteri heterotrof pada seri pengenceran $10^{-6}$ pada kedua ulangan 1 dan 2 lebih banyak dibandingkan dengan total kelimpahan bakteri heterotrof pada seri pengenceran $10^{-7}(\mathrm{BH} 1, \mathrm{BH} 2, \mathrm{BH} 3$, dan $\mathrm{BH} 4)$. Hal ini sesuai dengan konsep pengenceran bahwa semakin tinggi seri pengenceran maka total kelimpahan bakteri yang diencerkan juga akan semakin sedikit. Menurut Yuanita (2015), tujuan dari pengenceran bertingkat yaitu memperkecil atau mengurangi jumlah mikroba yang terdapat dalam cairan, maka semakin banyak tingkat pengenceran akan menghasilkan mikroba yang semakin sedikit. Agustinus et al. (2010) menyatakan bahwa bakteri tumbuh dominan pada pengenceran terendah pada setiap pengambilan sampel yang diidentifikasi berdasarkan sifat morfologi koloni dan sel serta sifat fisiologi dan biokimia.

Jenis koloni bakteri heterotrof $\mathrm{BH} 1, \mathrm{BH} 2$, $\mathrm{BH} 3$, dan $\mathrm{BH} 4$ dapat ditemukan pada kedua seri pengenceran $10^{-6}$ dan $10^{-7}$. Adapun jenis koloni bakteri heterotrof $\mathrm{BH} 5$ (pada ulangan 1), BH6 dan BH7 (pada ulangan 2) hanya dapat ditemukan dan diisolasi pada seri pengenceran $10^{-7}$. Hal ini dapat dipengaruhi oleh faktor lamanya waktu homogenisasi yang tidak sama ketika larutan sampel daging ikan kurisi antara seri pengenceran $10^{-6}$ dan $10^{-7}$ dihomogenkan menggunakan alat vortex. Akibatnya, pada seri pengenceran $10^{-6}$ tidak ditemukan adanya jenis koloni bakteri heterotrof $\mathrm{BH} 5, \mathrm{BH} 6$, dan $\mathrm{BH} 7$.

Homogenisasi merupakan proses emulsifikasi yang bertujuan untuk memperkecil ukuran fase terlarut agar terdispersi dengan baik dalam fase kontinu. Oleh karena homogenisasi dapat menghasilkan pengurangan ukuran fase terlarut dan sebaran yang merata (Kailaku et al. 2012), maka semakin lama waktu homogenisasi dilakukan, maka akan semakin homogen pula fase terdispersi yang dihomogenkan. Walaupun demikian, dapat diketahui bahwa total kelimpahan jenis koloni bakteri heterotrof tertinggi pada media TSA ditunjukkan oleh $\mathrm{BH} 3$ pada seri pengenceran $10^{-6}$ pada ulangan 2, yaitu sebesar 336 koloni bakteri.

Berdasarkan Figure 3 dapat diketahui bahwa total kelimpahan jenis koloni bakteri patogen pada seri pengenceran $10^{-1}$ lebih banyak dibandingkan dengan total kelimpahan jenis koloni bakteri patogen pada seri pengenceran $10^{-2}$, yaitu BPE1, BPE2, 


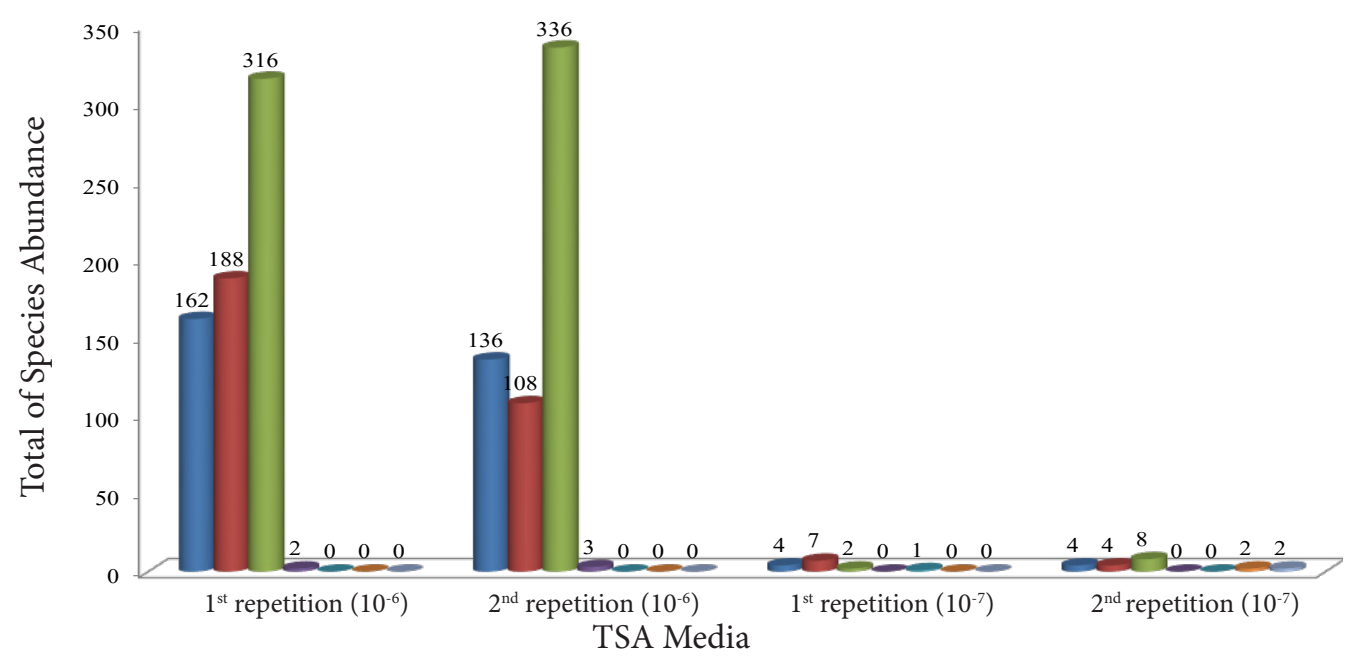

Figure 2 Total of species abundance of heterotrophic bacterial colonies from samples of kurisi fish meat on TSA media; $\quad$ BH1; $\square$ BH2; $\square$ BH3; $\square$ BH4; $\square$ BH5; $\square$ BH6; - BH7

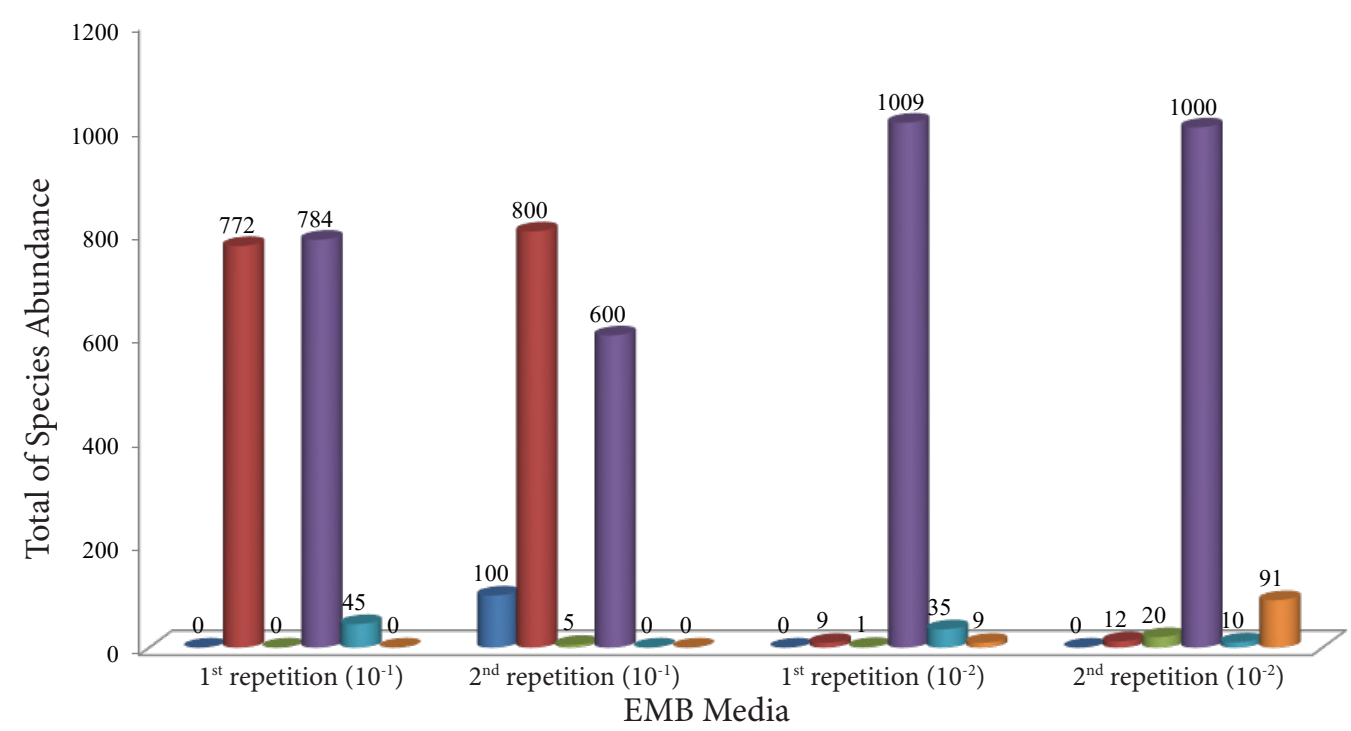

Figure 3 Total of species abundance of heterotrophic bacterial colonies from samples of kurisi fish

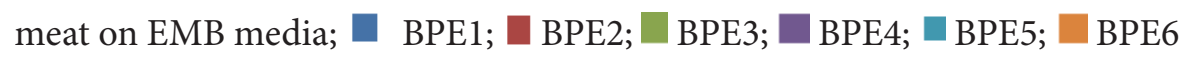

dan BPE5. Pengenceran dilakukan secara bertingkat (Putri dan Kurnia 2018), karena sampel yang tidak dilakukan pengenceran akan menghasilkan jumlah koloni bakteri yang sangat pekat dan besar kemungkinannya untuk terlalu banyak dihitung (TBUD). Menurut BPOM (2010), pengenceran yang dilakukan pada sampel bertujuan untuk mendapatkan koloni bakteri yang tumbuh secara terpisah agar dapat mudah dihitung dan dapat membantu terutama pada sampel dengan cemaran yang sangat tinggi.

Akan tetapi, total kelimpahan jenis koloni bakteri patogen BPE3, BPE4, dan
BPE6 pada seri pengenceran $10^{-1}$ lebih sedikit dibandingkan dengan total kelimpahan 3 jenis koloni bakteri patogen tersebut pada seri pengenceran $10^{-2}$. Hal ini dapat disebabkan pada saat dilakukan homogenisasi, larutan suspensi kurang homogen (Rosidah 2016) sehingga diperoleh total kelimpahan jenis koloni bakteri patogen yang lebih sedikit pada pengenceran terendah $\left(10^{-1}\right)$ dibandingkan pada pengenceran tertinggi $10^{-2}$ ). Walaupun demikian, dapat diketahui bahwa total kelimpahan jenis koloni bakteri patogen tertinggi pada media EMB ditunjukkan oleh BPE4 pada seri pengenceran $10^{-2}$ pada ulangan 


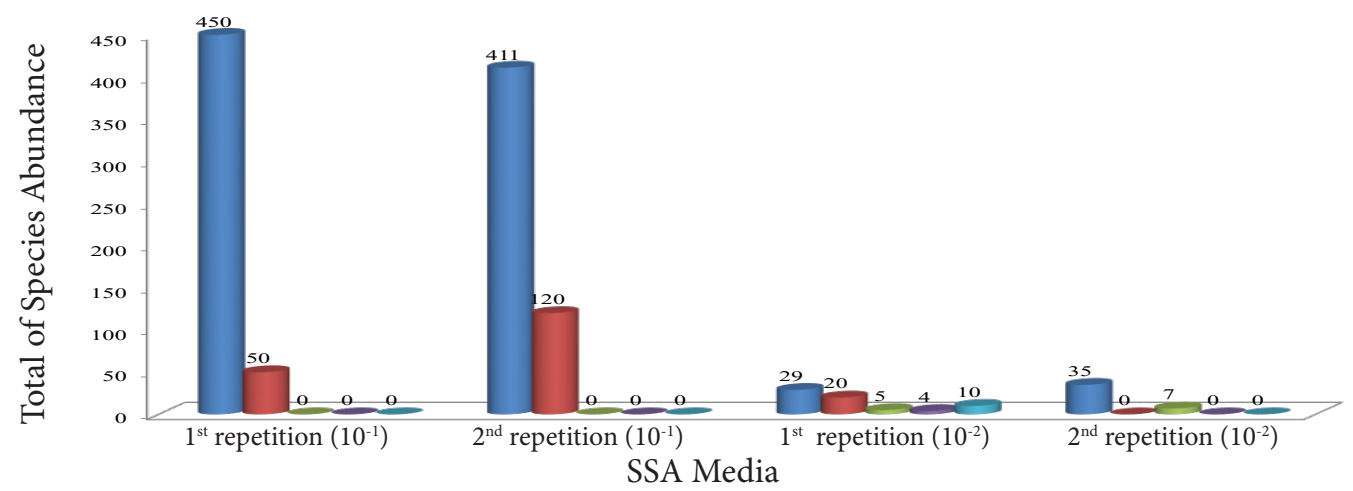

Figure 4 Total of species abundance of heterotrophic bacterial colonies from samples of kurisi fish meat on EMB media; BPS1; BPS2; BPS3; — BPS4; — BPS5

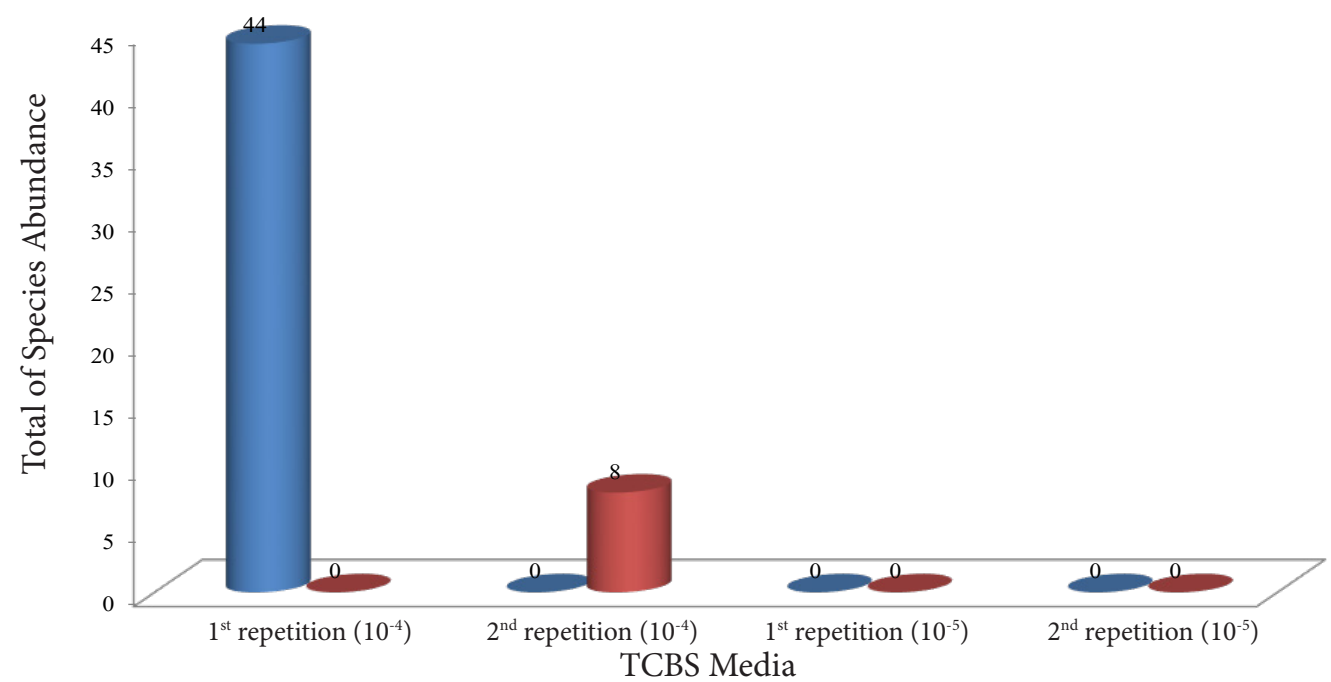

Figure 5 Total of species abundance of heterotrophic bacterial colonies from samples of kurisi fish meat on EMB media; $\quad$ BPT1; BPT2

1, yaitu sebesar 1009 koloni bakteri.

Berdasarkan Figure 4 dapat diketahui bahwa total kelimpahan jenis koloni bakteri patogen tertinggi pada media SSA ditunjukkan oleh BPS4 pada seri pengenceran $10^{-1}$ pada ulangan 1 , yaitu sebesar 450 koloni bakteri. Geetha et al. (2014) melaporkan total kelimpahan jenis koloni bakteri patogen Salmonella yang berhasil diisolasi dari spesies ikan U. vittatus, N. japonicus, dan P. hamrur pada media SSA. Total kelimpahan jenis koloni bakteri patogen Salmonella tertinggi terdapat pada spesies ikan N. japonicus, P.hamrur, dan $U$. vittatus secara berurutan sebesar 75, 50, dan 32 .

Berdasarkan Figure 5 dapat diketahui bahwa total kelimpahan jenis koloni bakteri patogen tertinggi pada media TCBS ditunjukkan oleh BPT1 pada seri pengenceran $10^{-1}$ pada ulangan 1 , yaitu sebesar 44 koloni bakteri. Geetha et al. (2014) melaporkan total kelimpahan jenis koloni bakteri patogen Vibrioyang berhasil diisolasi dari spesies ikan $U$. vittatus, N. japonicus, dan $P$. hamrur pada media SSA. Total kelimpahan jenis koloni bakteri patogen Vibrio tertinggi terdapat pada spesies ikan N. japonicus, Prianthus hamrur, dan Upeneus vittatus secara berurutan sebesar 102, 80, 62, 50, dan 32 .

\section{KESIMPULAN}

Kualitas daging ikan kurisi hasil tangkapan nelayan yang didaratkan di Tempat Pelabuhan Ikan Branta, Kabupaten 
Pamekasan memenuhi kriteria standar nilai yang dinyatakan oleh IAMS, ICMSF, dan BSN. N. japonicus terkontaminasi bakteri heterotrof $(8,59 \mathrm{Log} \mathrm{CFU} / \mathrm{g})$ maupun bakteri patogen dari kelompok koliform (3,72 Log CFU/g), Salmonella sp. (4,12 Log CFU/g), dan Vibrio sp. (5,41 Log CFU/g). Oleh karena itu, perlu dilakukan kegiatan penanganan hasil perikanan yang baik sesuai prosedur sanitasi dan higienisasi ikan di Pelabuhan Perikanan Branta, Pamekasan secara berkala.

\section{UCAPAN TERIMA KASIH}

Penulis mengucapkan terima kasih kepada Fakultas Pertanian Universitas Trunojoyo Madura atas terlaksananya penelitian ini melalui bantuan Dana Riset Penelitian Prodi Manajemen Sumberdaya Perairan 2019. Terima kasih kepada seluruh peserta Seminar Nasional Masyarakat Pengolahan Hasil Perikanan (MPHPI) 2019, Universitas Sriwijaya, atas saran, masukan dan komentar yang diberikan untuk perbaikan kualitas artikel ini.

\section{DAFTAR PUSTAKA}

Aagesen A, Hase M. 2014. Seasonal effects of heat shock on bacterial populations, including artificial Vibrio parahaemolyticus exposure, in the Pacific oyster, Crassostrea gigas. Food Microbiology. 38. 93-103.

Afshari M, Valinassab T, Seifabadi J, Kamaly E. 2013. Age determination and feeding habits of Nemipterus japonicus (Bloch, 1791) in the Northern Oman Sea. Iranian Journal of Fisheries Sciences. 12(2): 248264.

Agustinus F, Widanarni, Ekasari J. 2010. Kelimpahan dan keragaman jenis bakteri dalam air dan parameter imunitas ikan nila merah yang dipelihara dalam system bioflok dengan kepadatan ikan yang berbeda ( $25 \mathrm{ekor} / \mathrm{m}^{3}, 50 \mathrm{ekor} / \mathrm{m}^{3}$, dan 100 ekor $\left.\mathrm{m}^{3}\right)$. Jurnal Akuakultur Indonesia. 9(2): 157-167.

Agustiyani D, Ruly MKRM, Imamuddin H. 2010. Oksidasi nitrit oleh bakteri heterotrofik pada kondisi aerobic. Jurnal Biologi Indonesia. 6(2): 265-275.

Alaboudi AR, Ababne M, Osaili TM, Al
Shloul K. 2016 . Detection, identification, and prevalence of pathogenic Vibrio parahaemolyticus in fish and coastal environment in Jordan. Journal of Food Science. 81(1): 130-134.

Amagliani G, Brandi G, Schiavano GF. 2012. Incidence and role of Salmonella in seafood safety (Review). Food Research International. 45(2). 780-788.

Amine AM. 2012. Biology and assessment of the tread fin bream Nemipterus japonicus in Gulf of Suez, Egypt. Egyptian Journal of Aquatic Biology and Fisheries. 16(2): 4757.

Asriyana, SyafeiLS. 2012. Perubahan ontogenik makanan ikan kurisi, Nemipterus hexodon (famili: Nemipteridae) di Teluk Kendari. Jurnal Iktiologi Indonesia. 12(1): 49-57.

Aung TH. 2019. Age determination of Nemipterus japonicus in Thabaw-seik, Myanmar using sagittal otolith and scales ring. Asian Journal of Research in Biosciences. 1(2): 50-54.

Babu PJC, Rao NL. 2014. Microbiological examination of three types of common edible marine fishes from Visakhapatnam Fishing Harbour, East Coast of India. International Journal of Engineering Sciences \& Research Technology. 3(7): 289-292.

BPOM (Badan Pengawas Obat dan Makanan) Republik Indonesia. 2010. Kejadian luar biasa keamanan pangan. Buletin Keamanan Pangan. 17 (1): 15.

Brooks GF, Carroll KC, Butel JS, Morse SA. 2013. Mikrobiologi Kedokteran Jawetz, Melnic \& Adelberg Edisi 25. Jakarta: EGC.

[BSN] Badan Standardisasi Nasional. 2006. Cara Uji Mikrobiologi. Penentuan Angka Lempeng Total (ALT) pada Produk Perikanan. SNI 01.2332.3-2006. Jakarta (ID): Badan Standardisasi Nasional.

[BSN] Badan Standardisasi Nasional. 2009. Batas Maksimum Cemaran Mikroba dalam Pangan. SNI 7388:2009. Jakarta: Badan Standardisasi Nasional.

Cappucino JG, Sherman N. 2002. Microbiology A Laboratory Manual, $6^{\text {th }}$ ed. Menlo Park: The Benjamin/Cummings Publishing Company, Inc: xvi +491 hlm.: Benjamin Cummings. 
Chatterjee SN, Syed AA, Mukhopadhyay B. 2014. Diversity of soil bacteria in some villages areas adjoining to Joypur Forest of Bankura District of West Bengal, India. International Journal of Environmental Biology. 4(1): 67-70.

Commision Regulation (EC) No 2073/2005 of 15 November 2005 on Microbiological Criteria for Foodstuff. OJL 338. 22/12/2005. P. 1-6.

ČSN 569609. 2008. Guides to good hygiene and manufacturing practicemicrobiological criteria for foods Principles for the establishment and application.

Devi AR, Susilowati A, Setyaningsih R. 2019. Enumerasi dan uji patogenitas Vibrio sp. yang terdapat pada kerang darah (Anadara granosa) di kawasan pantai wisata Yogyakarta. Prosiding Seminar Nasinonal Masyarakat Biodiversitas Indonesia. 5(1): 357-361.

Dinas Kelautan dan Perikanan Provinsi Jawa Timur, 2018. Produksi Perikanan di Jawa Timur. Surabaya (ID): Dinas Kelautan dan Perikanan Provinsi Jawa Timur.

Elhadi N, Radu S, Chen C-H, Nishibuuchi M. 2004. Prevalence of potentially pathogenic Vibrio species in the seafood marketed in Malaysia. Journal of Food Protection. 67(7). 169-1475.

ElHaweet AEA. 2013. Biological studies of the invasive species Nemipterus japonicus (Bloch, 1791) as a Red Sea immigrant into the Meditteranian. The Egyptian Journal of Aquatic Research. 39(4): 267-274.

Engelkirk PG, Duben JL. 2008. Laboratory Diagnosis of Infectious Diseases. Baltimore: Wolters Kluwer Health/ Lippicont Williams \& Wilkins.

Ervianti, Herpandi, Baehaki A. 2017. Karakteristik fisiko kimia dan sensoris burger kerang darah (Anadara granosa). FistecH-Jurnal Teknologi Hasil Perikanan. 6(2): 134-144.

Geetha S, Sri LB, Karuna Y, Rao VG, Krishna NM, Reddy NMS, K Bhavani, Babu KR. 2014. Microbiological examination of three types of common edible marine fishes from Visakhapatnam fishing harbor, east coast of India. World Journal of Fish and Marine Sciences. 6(5): 471-474.

Gorner F, Valik L. 2004. Applied Food Microbiology (Aplikovana mikrobiologia pozivatin). Brtislava, Male Centrum, PPA. 528 p. ISBN 80-967064-9-7.

Hamidah MN, Rianingsih L, Romadhon. 2019. Aktivitas antibakteri isolat bakteri asam laktat dari peda dengan jenis ikan berbeda terhadap E. coli dan S. aureus. Jurnal Ilmu dan Teknologi Perikanan. 1(2): 11-21.

Hikmawati F, Susilowati A, Setyaningsih R. 2019. Deteksi jumlah dan uji patogenitas Vibrio spp. pada kerang hijau (Perna viridis) di kawasan wisata pantai Yogyakarta. Prosiding Seminar Nasional Masyarakat Biodiversitas Indonesia. 5(2): 334-339.

Horseman MA, Surani S. 2011. A comprehensive review of Vibrio vulnificus: an important cause of severe sepsis and skin and soft-tissue infection. International Journal of Infectious Diseases. 15(3): 157-166.

IAMS (International Association of Microbiological Societies). 1962. ( $w w w$. microbialstandard.com).

ICMSF (International Commision of Microbiological Specification for Food), 1986. Microorganisms in Food 2. Sampling for Microbiological Analysis: Principles and Specific Applications, $2^{\text {nd }}$ edition. Toronto (CA): University of Toronto Press.

Ihsan B, Abdiani IM, Imra. 2018. Deteksi dan identifikasi bakteri Salmonella spp. pada ikan bandeng yang dijual di Pasar Gusher Kota Tarakan. Jurnal Harpodon Boerneo. 11(1): 46-51.

Ihsan B, Retnaningrum E. 2017. Isolasi dan identifikasi bakteri Vibrio sp. pada kerang kapah (Meretrix meretrix) di Kabupaten Trenggalek. Jurnal Harpodon Borneo. 10(1): 23-27.

IngrI.2010.FishQualityandProcessing.(Jakosta zpracování $r y b) . \quad 2^{\text {nd }}$ ed. Brno: Mendelova univerzita $v$ Brně, 102 p. ISBN 978-80-7375-382-5.

Iwamoto M, Ayers T, Mahon BE, Swerdlow DI. 2010. Epidemiology of seafoodassociated infection in the United Stated. Clinical Microbiology Reviews. 23(2). 399-411. 
Kailaku SI, Hidaya T, Setiabudy DA. 2012. Pengaruh kondisi homogenisasi terhadap karakteristik fisik dan mutu santan selama penyimpanan. Jurnal Littri. 18(1):31-39

Kementerian Kelautan dan Perikanan. 2018. Produktivitas Perikanan Indonesia pada: Forum Merdeka Barat 9 Kementerian Komunikasi dan Informatika. Diakses dari https://kkp.go.id/wp-content/ uploads/2018/01/KKP-Dirjen-PDSPKPFMB-Kominfo-19-Januari-2018.pdf

Khakim L, Rini CS. 2018. Identifikasi Escherichia coli dan Salmonella sp. pada air kolam renang Candi Pari. Journal of Medical Laboratory Science/Technology. 1(2): 84-93.

Komprda T. 2004. General Food Hygiene (Obecna hygiene potravin), $2^{\text {nd }}$. Brno: MZLLU: 112, p. ISBN 80-7157-7157-X.

Kurniawan R, Dessy Y, Syahril N. 2012. Analisis bakteri pembentuk histamin pada ikan tongkol di Perairan Pasie Nan Tigo Koto Tangah Padang Sumatra Barat. Jurnal Teknik Kimia. 2(2): 127-135.

Lokollo E, Mailoa MN. 2020. Teknik penanganan dan cemaran mikroba pada ikan layang segar di pasar tradisional Kota Ambon. Jurnal Pengolahan Hasil Perikanan Indonesia. 21(3): 103-111.

Laluraa LFH, Loho HJ, Mewengkang HW. 2014. Identifikasi bakteri Escherichia pada ikan selar (Selaroides sp.) bakar di beberapa resto di Kota Manado. Jurnal Media Teknologi Hasil Perikanan. 2(1): 5-8.

Lestari NW, Budiharjo G, Pangastuti A. 2016. Bakteri heterotrof aerobik asal saluran pencernaan ikan sidat (Anguilla bicolor bicolor) dan potensinya sebagai probiotik. Bioteknologi. 13 (1): 9-17.

Luo YW, Friedrichs MAM, Doney SC, Church MJ, Ducklow HW. 2010. Oceanic heterotrophic bacterial nutrition by semilabile DOM as revealed by data assimilative modeling. Aquatic Microbiology Ecology. 60:273-287.

Markenih E. 2016. Sanitasi dan higienitas serta pengaruhnya terhadap kualitas ikan yang didaratkan di pelabuhan perikanan pantai Blanakan, Subang. [Skripsi]. Bogor (ID): Institut Pertanian Bogor.
Murniyati AS, Sunarman. 2000. Pendinginan, Pembekuan, dan Pengawetan Ikan. Yogyakarta: Kanisus.

Nurhayati, Samallo IM. 2013. Analisis degradasi polutan limbah cair pengolahan rajungan (Portunus pelagicus) dengan penggunaan mikroba komersial. Jurnal Ilmiah Fakultas Teknik, LIMITS. 9(1): 1-13.

Oktaviyani S, Boer M, Yonvitner. 2016. Aspek Biologi Ikan Kurisi (Nemipterus japonicus) di Perairan Teluk Banten. BAWAL Widya Riset Perikanan Tangkap. 8(1): 21-28.

Patil SS, Koli JM, Sharangdher ST, Balange AK, Sharangdher MT. 2013a. Development of "Fish Pakoda" from pink perch (Nemipterus japonicus) meat. Ecology, Environment, and Conservation. 19(2): 181-183.

Patil SS, Koli JM, Sharangdher ST, Sharangdher MT. 2013b. Storage characteristics of "fish pakoda" from pin perch (Nemipterus japonicus) meat at $4^{\circ} \mathrm{C}$. Ecology, Environment and Conservation. 19(13): 877-880.

Pelczar E, Melnick JL, Adelberg EA. 2007. Dasar-Dasar Mikrobiologi 1. Jakarta (ID): Universitas Indonesia Press.

Prabakaran TE, Thompson RJ, Samuel VD. 2014. A Study on the morphometric and meristic Characters of the Threadfin Bream (Nemipterus Japonicus, Bloch 1791) off Chennai Coast. Indian Journal of Applied Research. 4(1): 521-524.

Putri AP, Kurnia P. 2018. Identifikasi keberadaan bakteri coliform dan total mikroba dalam es dung-dung di sekitar kampus Universitas Muhammadiyah Surakarta. Media Gizi Indonesia. 41-48

Rahayu WP, Adhi W. 2016. Penerapan good logistic practices untuk produk perikanan. Jurnal Manajemen Transportasi dan Logistik. 3(2): 129-147.

Rahmatang, Prihajatno M, Irwan. 2019. Waktu transit, nilai organoleptik, dan nilai keasaman $(\mathrm{pH})$ : hasil tangkapan purse seine. PENA Akuatika. 18(1): 28-40.

Rahmiati. 2016. Analisis bakteri SalmonellaShigella pada kuah sate pedagang kaki lima. BioLink Jurnal Biologi Lingkungan, 
Industri, Kesehatan. 3(1):31-36.

Rao MVH, Ghosh S, Sreeramulu K, Mahesh VU, Kumar MS, M Muktha. 2017. Dynamics of Nemipterus japonicus (Bloch) stocks along the north-east coast of India. Indian Journal of Geo Marine Sciences. 47(9): 1761-1768.

Rinawati LP, Arsana IN, Juliasih NKA. 2015. Pengaruh konsentrasi natrium chloride pada media alkaline peptone water terhadap pertumbuhan baktri Vibrio cholera. Meditory. 3(1): 19.

Romadhon Z. 2016. Identifikasi Bakteri Escherichia coli dan Salmonella sp. pada Siomay yang Dijual di Kantin SD Negeri di Kelurahan Pisangan, Cirendeu, dan Cempaka Putih. [Skripsi].Jakarta (ID): UIN Syarif Hidayatullah.

Rosidah U. 2016. Tepung ampas tahu sebagai media pertumbuhan bakteri Serratia marcescens. [Skripsi] Semarang (ID): Universitas Muhammadiyah Semarang.

Rosmaniar. 2011. Dinamika Biomassa Bakteri dan Kadar Limbah Nitrogen pada Budidaya Ikan Lele (Clarias gariepinus) Intensif Sistem Heterotrofik. [Skripsi]. Jakarta (ID): Universitas Islam Syarif Hidayatullah.

Sabdaningsih A, Budiharjo A, Kusdiyantini E. 2013. Isolasi dan karakterisasi morfologi koloni bakteri asosiasi alga merah (Rhodophyta) dari perairan Kutuh Bali. Jurnal Biologi. 2(2): 11-17.

Sankar S, Sujith P, Jayalakshmi. 2013. Microbial study and proximate composition of six marine fish species in mudasalodai coastal region. Research Article Biological Sciences. 3(3): 398-404.

Sari NI. 2014. Isolasi dan Karakterisasi Bakteri Tanah di Kecamatan Pattallassang Kabupaten Gowa. [Skripsi]. Makassar (ID): UIN Alauddin Makassar.

Sarman V, Hitesh K, Vinaykumar V, Mahendra P, Piyush V. 2018. Biological aspects of threadfin bream Nemipterus japonicus (Bloch 1791) along coast of Saurastra, Gujarat. Journal of Fiseheries and Life Sciences. 3(1): 34-38.

Suvanich V, Marshall DL, Jahncke ML. 2000.
Microbiological and color quality changes of channel catfish frame mince during chilled and frozen storage. Journal of Food Science. 65(1): 151-154.

Souza BWS, Cerqueira MA, Ruiz HA, Martins JT, Casariego A, Teixeira JA. 2010. Effect of chitosan based coatings on the shelflife of salmon (Salmo salar). Journal of Agricultural And Food Chemistry. 58 (21): 11456-11642.

Terenjeva M, Eizenberga I, Valcina O., Novoslavskij A, Starzdina V, Berzins A. 2015. Prevalence of foodborne pathogens in freshwater fish in Latvia. Journal of Food Protection. 78(11). 2093-2098.

Violentina GAD, Ramona Y, Mahardika IGNK. 2015. Identifikasi bakteri dari ikan tongkol (Euthynnus affinis) yang diperdagangkan di Pasar Ikan Kedonganan, Bali. Jurnal Biologi. 19(2): 58-62.

[WHO] World Health Organization. 1982. Bacteriological examination. Examination of Water Pollution Control. 3: 273-531.

Wibowo APW, Andrivani R. 2016. Perhitungan Jumlah Bakteri Escherichia coli dengan Pengolahan Citra Melalui Metode Thresholding dan Counting Morphology. JITTER (Jurnal Ilmiah Teknologi Informasi Terapan. 2 (3): 235243.

Yang X, Wu Q, Zhang J, Huang J, Chen L, Liu S, Yu S, Cai S. 2015. Prevalence, enumeration, and characterization of Salmonella isolated from aquatic food products from retail markets in China. Food Control. 57: 308-331.

Yuanita M, Hendrawan Y, Yulianingsih R. 2015. Analisis kuantitatif mikrobiologi pada makanan penerbangan (Arofood ACS) Garuda Indonesia berdasarkan TPC (Total Plate Count) dengan metode pourplate. Jurnal Keteknikan Pertanian Tropis dan Biosistem. 3(3): 239.

Yuliani NS, Wera E, Bulu PM. 2016. Identifikasi bakteri Salmonella sp dan jumlah total kontaminan bakteri coliform pada ikan kembung (Scomber sp.) yang dijual di Pasar Inpres dan Oeba. Buletin Pertanian Terapan. 1(1): 16-20. 